MATEC Web of Conferences 47, 01016 (2016)

DOI: $10.1051 /$ matecconf/20164701016

(C) Owned by the authors, published by EDP Sciences, 2016

\title{
Isolation of Sulphate Reduction Bacteria (SRB) to Improve Compress Strength and Water Penetration of Bio-Concrete
}

\author{
A. Faisal Alshalif ${ }^{1}$, J. M.Irwan ${ }^{1, a}$, N. Othman ${ }^{2}$ and L. H. Anneza ${ }^{1}$ \\ ${ }^{1}$ Jamilus Research Center, University Tun Hussein Onn, Malaysia, 86400 Parit Raja, Johor, Malaysia \\ ${ }^{2}$ Faculty of Civil and Environmental Engineering, University Tun Hussein Onn, Malaysia, 86400 Parit Raja, Johor, \\ Malaysia.
}

\begin{abstract}
The objective of this study is to isolate sulphate reduction bacteria (SRB) from acid mire water collected at Sg Pelepah Kota Tinggi, Johor Malaysia. The isolation process was conducted in high alkaline and anaerobic conditions to sustain the bacteria in concrete environment. Properties tests such as compressive strength and water penetration were conducted. The result showed that optimal growth condition of sulphate reduction bacteria is $\mathrm{pH} 9-10$. It was also observed that the bacteria is a coccus shape after gram staining process. The bacteria was used after 10 days of culturing prior to growth curve measurement. The liquid culture containing sulphate reduction bacteria were used at $1 \%, 3 \%$ and $5 \%$ as replacement ratio of water content. Concrete specimens were cured in the air conditions for 7, 14 and 28 days. Maximum increment on compressive strength was $13.0 \%$ and decrement in water penetration was $8.5 \%$ occurred with $5 \%$ of SRB. The enhancement in compressive strength and water penetration performance was due to calcium precipitation within concrete pores. Image of scanning electronic microscopy (SEM) showed bacteria sustained and survived in concrete environment by reducing diameter of pores in concrete specimens.
\end{abstract}

\section{Introduction}

Concrete is the first most consumed material in construction projects. The application of concrete is rapidly increasing with the increasing of types of concrete worldwide. Recently, concrete technology presents many types concrete which are economically and friendly with environment. Today innovation is leading to natural solution for environmental impacts of concrete as sustainable alternative. However, the development of a sustainable concrete is urgently needed for environmental reasons. Biotechnology, applied to create new type of concrete namely bio- concrete using microorganism as natural way to improve concrete properties [1].

Therefore, bio-concrete is the used many types of bacteria whereas, the most popular bacteria used in concrete are (Bacillus Pasteurii Pseudomonas Aeruginosa, Bacillus Sphaericus, Ureolytic and Shewanella) to produce carbonate [8-11]. The presence of calcium sources in cement material plays an important role in producing calcium carbonate through enzyme reaction from those bacteria. Metabolic activities of some specific microorganisms in bio-concrete resulted by microbial mineral precipitation which in role improve the overall behavior of concrete and help in healing

\footnotetext{
${ }^{a}$ Corresponding author : irwan@uthm.edu.my
} 
process of pores and cracks [6]. Bio-concrete application is rapidly increasing worldwide and the development of bacteria mediated bio-concrete is urgently needed for environmental reasons $[2,3]$.

SRB has the ability to precipitate the dolomite consisting of a carbonate of calcium and magnesium. Precipitation of calcium carbonate is the essentially role of sulphate reduction bacteria which functionally has the ability to create an alkaline environment through various physiological activities [4]. Concrete technology used many types of additional materials to improve concrete properties such as foamed agent, super plasticizers or pozzolanic materials fly ash, biomass, silica fume, and other admixtures materials [5]. In addition, adding bacteria to the conventional concrete or other types of concrete to produce new type of concrete namely bio-concrete. Therefore, bio- concrete can be considered as modern concrete comparing to conventional concrete. The used of bacteria in different types of concrete to improved concrete properties and healing process such as fly ash concrete and concrete incorporating silica fume. Furthermore, the potential of bacteria in bio- concrete to act as self-healing of micro-cracks in concrete has proven to be a promising future [7].

Based on the statements above, it can be seen clearly bacteria have the ability to precipitate calcium which in line with filling pores and enhance concrete properties. But the most problem restricting the growth of bacteria inside the concrete were high alkaline and anaerobic conditions. In this study, (SRB) isolated with high alkaline and anaerobic condition with the aim to survive in the concrete environment. Hence, the evaluation of bio-concrete behavior in compressive strength and water penetration properties should be optimized.

\section{Methodology}

\subsection{Isolation of bacteria}

SRB applied to concrete as surface treatment. Based in the previous publications, conducted by other researchers, bacteria with gram positive capable to precipitate carbonate calcium in concrete through the biological process in concrete mix [9, 11-13].

Source of SRB from acid mire water collected from $\mathrm{Sg}$ Pelepah Kota Tinggi, Johor Malaysia. Whereas, the isolation process of SRB was following; enrichment, serial dilution, streaking plate, strain purification, gram staining and microscopy. SRB was enriched under special environment to tolerate the high alkalinity and anaerobic conditions for ensuring self sustain in the concrete. In this study magnesium sulphate heptahydrate AR (MgSO4.7H2O) was added to simulate sulphate environment during isolation. The compositions of media for control and SRB were prepared as follow:

a) Composition of sulphate reduction bacteria sample (SRB) consists of $25 \mathrm{ml}$ (nutrient broth $+10 \mathrm{ml}\left(\mathrm{Mg} \mathrm{SO} 4.7 \mathrm{H}_{2} \mathrm{O}\right)+1 \mathrm{ml}$ (water from Sg pelepah Kota Tinggi).

b) Composition of control sample for sulphate reduction bacteria consist of $25 \mathrm{ml}$ (nutrient broth) $+10 \mathrm{ml}\left(\mathrm{Mg} \mathrm{SO}_{4} .7 \mathrm{H}_{2} \mathrm{O}\right)$.

Traditionally, bacteria can't survive in high alkaline environment and anaerobic conditions due to high $\mathrm{pH}$ value will effect microbial life which influence the dissociation and solubility of many molecules in bacteria enzyme [14]. Therefore, after samples preparation $\mathrm{pH}$ was adjusted in alkaline condition. The $\mathrm{pH}$ adjustment was done using $\mathrm{NaOH}$ until $\mathrm{pH}$ value in the range of 9-10. The other condition that was monitored along this study is anaerobic condition of the enrichment. Nitrogen gas was purged in the enrichment flask before enrichment started. The concentration of oxygen should be at $0 \mathrm{ppm}$ and was measured with dissolve oxygen meter. The flask was shaked at room temperature. The adjustment of $\mathrm{pH}$ and anaerobic condition were done every day over the enrichment period of 20 day. 


\subsection{Concrete mixture proportion and materials properties}

Concrete mixtures was designed according to (DOE) Department of Environment for target 28 days compressive strength of $30 \mathrm{MPa}$. Concrete mix proportion used $0.54 \mathrm{w} / \mathrm{c}$ to achieved the target strength as illustrated the details in Table 1. Ordinary portland cement was used and manufactured by Holcim Malaysia which the composition and specification complying with all requirement defined by BS EN 197-1:2000 [17]. The size of fine aggregate was below 5mm while coarse aggregate was in the range $(12-20) \mathrm{mm}$. Whereas, the requirement size of aggregate in concrete used sieve analysis test which conducted according to BS 882-1992 [18].

Table 1. Mix proportion of bio-concrete with different percentages of SRB.

\begin{tabular}{|c|c|c|c|c|c|}
\hline $\begin{array}{c}\text { Percentage } \\
\left(\begin{array}{c}\%) \text { of bacteria in } \\
\text { batch }\end{array}\right.\end{array}$ & $\begin{array}{c}\text { Cement } \\
(\mathbf{k g})\end{array}$ & $\begin{array}{c}\text { Water } \\
\mathbf{( k g )}\end{array}$ & $\begin{array}{c}\text { Fine } \\
\text { aggregate } \\
\mathbf{( k g )}\end{array}$ & $\begin{array}{c}\text { Coarse } \\
\text { aggregate } \\
\mathbf{( k g )}\end{array}$ & $\begin{array}{c}\text { Bacteria } \\
\text { growth medium } \\
(\mathbf{1 k g}=\mathbf{1 L})\end{array}$ \\
\hline $0 \%$ & 420 & 210 & 685 & 1115 & 0 \\
\hline $1 \%$ & 420 & 207.9 & 685 & 1115 & 2.1 \\
\hline $3 \%$ & 420 & 203.7 & 685 & 1115 & 6.3 \\
\hline $5 \%$ & 420 & 199.5 & 685 & 1115 & 10.5 \\
\hline
\end{tabular}

\subsection{Preparation of test specimens}

Concrete cubes were prepared with different concentration of sulphate reduction bacteria in growth medium which replace $1 \%, 3 \%$ and $5 \%$ of water content. The cell concentration was determined from the bacterial growth curve made by observing the maximum turbidity was $710 \mathrm{NTU}$ at day 10 . Control concrete specimens were casted with out any additional of SRB. All experiments were performed in triplicates and curried in the dry conditions along the curing period.

\subsection{Compressive strength test}

Control concrete was designed using (DOE) to reach $30 \mathrm{MPa}$ on compressive strength at 28 day of curing period. For bio-concrete mixes water was partially replace with $1 \%, 3 \%$ and $5 \%$ (SRB) liquid culture by weight of water. After casting control sample and different mix of bio- concrete the mortar demoulding in cubs with size of $150 \mathrm{~mm} \times 150 \mathrm{~mm} \times 150 \mathrm{~mm}$ to be tested on $7 \mathrm{th}, 14$ th and 28th day of curing. The test was carried out using compressive strength Test Machine to conduct according to BS EN 12390- 3:2002 [19].

\subsection{Water penetration test}

Water penetration test was conducted according to BS EN 12390-8 [20] in ordure to determine the increase in resistance towards water penetration in concrete specimens as shown in Figure 1. The cubes molds of $150 \mathrm{~mm} \times 150 \mathrm{~mm} \times 150 \mathrm{~mm}$ were prepared both with and without (SRB). Concrete specimens were cured in dry air for 7th, 14th and 28th days. After curing the specimens water penetration test machine siting with constant pressure of $5 \mathrm{KPa}$ for 72 hours to measure the water penetration depth, then specimens is splitting in half and the maximum depth of penetration of water measured in $(\mathrm{mm})$. 


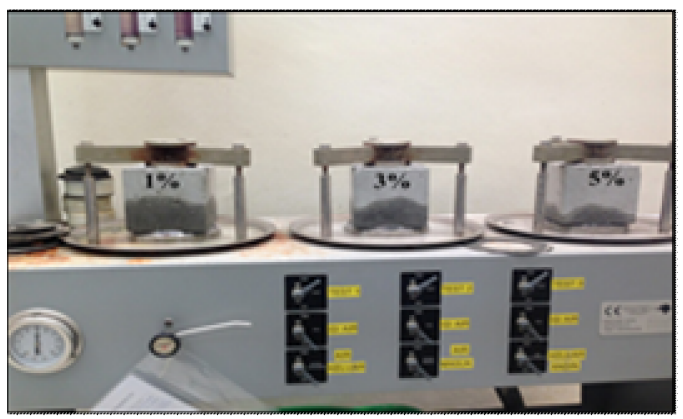

Figure1. Water penetration test.

\section{Results and Discussion}

\subsection{Compressive strength}

The compressive strength of bio-concrete increased gradually along 7, 14 and 28 days using different ratio of (SRB) liquid culture with $1 \%, 3 \%$ and $5 \%$ to replace water. Furthermore, the results emerged the maximum increment of compressive strength were with specimens contained $5 \%$ and the lower increment was with $1 \%$ of SRB. On the other hand, bio-concrete specimens contained $3 \%$ of SRB display good performance in compressive strength whereas; the results was closed to the specimen with $5 \%$ of SRB specially at 28 days as shown in Figure 2. The compressive strength result of bioconcrete contains $1 \%, 3 \%$ and $5 \%$ of SRB increased comparing to the control samples by $5.9 \%$, $11.7 \%$ and $13.0 \%$ respectively at 28 days of curing time. Therefore, the result of compressive strength of concrete increase with the increment of SRB replacement ratio. The observation of the enhancement in compressive strength using (SRB) was due to deposition of calcium which conform the precipitation of $\mathrm{CaCO} 3$ on the microorganism cell surfaces and within the pores in side the concrete, which plug the pores within the binder matrix. Similar results were reported by other researchers $[3,15]$.

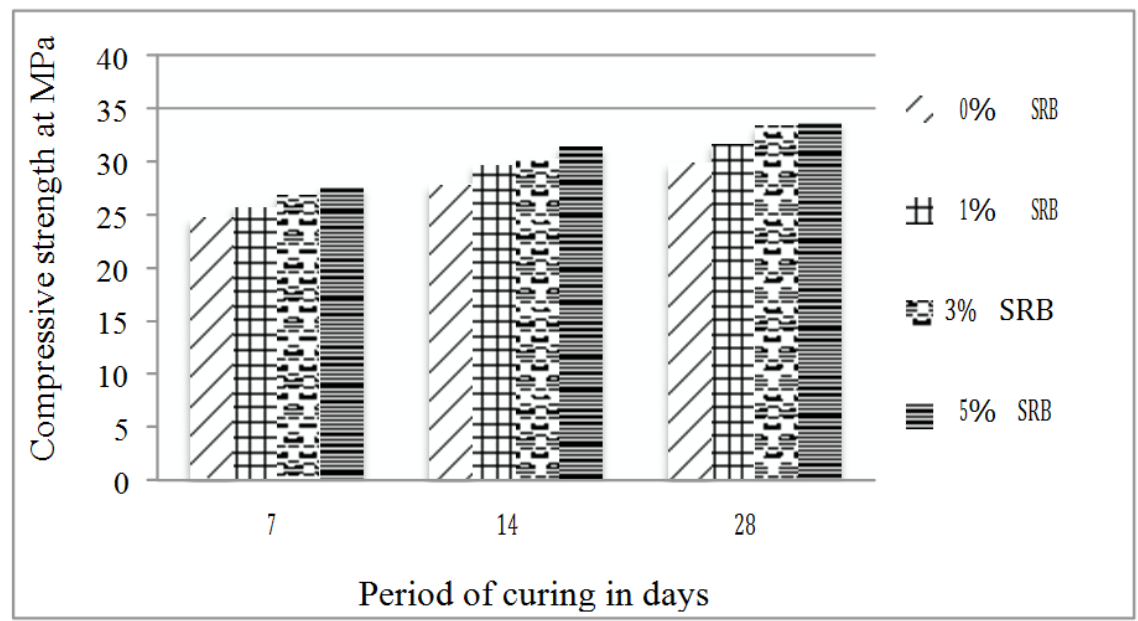

Figure 2. Compressive strength of concrete with different ratio of SRB. 


\subsection{Water penetration}

The results presented reduction of water penetration with all replacements ratio of water $1 \%, 3 \%$ and $5 \%$ by SRB in bio-concrete specimens. Also indicated that, the increment of (SRB) had inverse relationship with reduction of water penetration in bio-concrete specimens. It was estimated that, the highest improvement was determined with $5 \%$ and the lowest performance was with $1 \%$ of (SRB) growth medium in bio-concrete mix. The decrement shows that at 28 day, the water penetration reduce by $5.3 \%, 7.3 \%$ and $8.5 \%$ for $1 \%, 3 \%$ and $5 \%$ of (SRB) as illustrate in Figure 3.Having bacteria in concrete could reduce the water permeability. Therefore, it increases the durability of concrete as it would prevent water from seeping into concrete to cause carbonation of steel and chlorination which would jeopardize the strength of the structure and cause the whole building to be less durable than intended to [16].

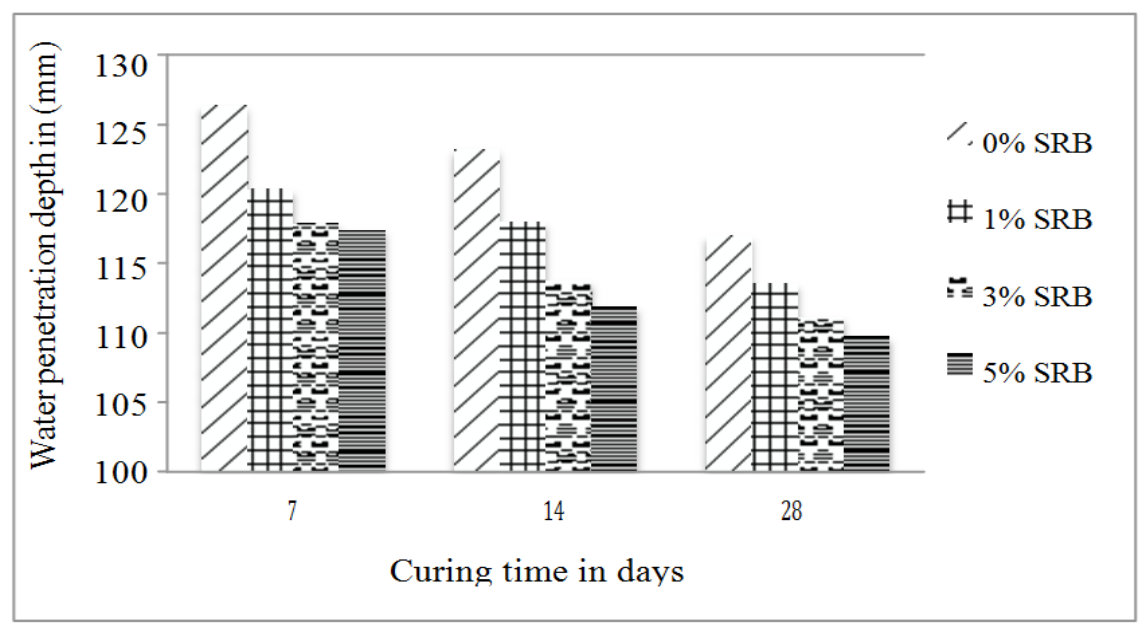

Figure 3. Water penetration depth with different ratio of SRB.

\section{Conclusion}

Out of all isolated cultures developed and tested of sulphate reduction bacteria it can be concluded that, (SRB) successfully isolated to survive in the alkaline environment in the range of 9-11 pH with anaerobic conditions. Furthermore, using of (SRB) in concrete increase the compressive strength and decrease of water penetration. Whereas, the highest increment in compressive strength of bio concrete was $13 \%$ with $5 \%$ of (SRB) compared to the control specimens at 28 days with same curing conditions. On the other hand, the maximum decrement of water penetration was $8.5 \%$ with replacement ratio $5 \%$ of (SRB) compared to the control sample at 28 days.

\section{Acknowledgment}

This study has been granted by the Ministry of Education (MOE) under Fundamental Research Grant Scheme (FRGS Vot. 1211) and supported by Universiti Tun Hussien Onn Malaysia (UTHM).

\section{References}

[1] G.M. Gonsalves, Bioconcrete- A Sustainable Substitute for Concrete, Master Thesis, Polytechnic University of Catalonia, Barcelona, Spain, (2011).

[2] R. Siddique and N. K. Chahal, Effect of ureolytic bacteria on concrete properties, Construction and Building Materials, 25, 3791-3801, (2011). 
[3] V. Achal, A. Mukerjee and M.S. Reddy, Biogenic treatment improves the durability and remediates the cracks of concrete structures, Construction and Building Materials, 48, 1-5, (2013).

[4] L.K. Baumgartner, R.P. Reid, C. Dupraz, A.W. Decho, D.H. Buckley and J. R. Spear, Sulfate reducing bacteria in microbial mats: Changing paradigms, new discoveries, Sedimentary Geology, 185, 131-145, (2006).

[5] R. Rajamma, L. Senff, M.J. Ribeiro, J.A. Labrincha, R.J. Ball and G.C. Allen, Biomass fly ash effect on fresh and hardened state properties of cement based materials, Composites Part B: Engineering, 77, 1-9, (2015).

[6] F. Nosouhian, D. Mostofinejad and H. Hasheminejad, Influence of biodeposition treatment on concrete durability in a sulphate environment, Biosystems Engineering, 133, 141-152 (2015).

[7] N. Chahal, R. Siddique and A. Rajor, Influence of bacteria on the compressive strength, water absorption and rapid chloride penetrationof concrete incorporating silica fume, Construction and Building Materials, 37, 645-651 (2012).

[8] S.K. Ramachandran, V. Ramakrishnan and S.S. Bang, Remediation of concrete using microorganisms, ACI Materials Journal, 98(1), 3-9, (2001).

[9] P. Ghosh, S. Mandal, B.D. Chattopadhyay and S. Pal, Use of microorganism to improve the strength of cement mortar, Cement and Concrete Research, 35, 1980-1983, (2005).

[10]F. Pacheco-Torgal and J.A Labrincha, Biotech cementitious materials: some aspects of an innovative approach for concrete with enhanced durability, Construction and Building Materials, 40, 1136-1141, (2013).

[11] S.M. Al-Thawadi, Ureolytic bacteria and calcium carbonate formation as a mechanism of strength enhancement of sand, J. Adv. Sci. Eng. Res., 1(1), 98-114, (2011).

[12]N. Chahal, R. Siddique and A. Rajor, Influence of bacteria on the compressive strength, water absorption and rapid chloride penetrationof fly ash concrete, Construction and Building Materials, 28, 351-356, (2012).

[13]R. Demirboğa, F. Karagöl, R. Polat and M. A. Kaygusuz, The effects of urea on strength gaining of fresh concrete under the cold weather conditions, Construction and Building Materials, 64, 114-120, (2014).

[14]R.C.J. Subhashree Parida, Kailash Chandra Samal and Pradeep Kumar Chand, isolation and identification of pathogenic bacteria from brackish waters of Chilika Lagoon, Odisha, India for pharmaceutical use, Malaysian Journal of Microbiology, 8(3), 197-202, (2012).

[15]H.K. Kim, S.J. Park, J.I. Han and H.K. Lee, Microbially mediated calcium carbonate precipitation on normal and lightweight concrete, Construction and Building Materials, 38, 10731082, (2013).

[16]N. De Belie and W. De Muynck, Crack repair in concrete using biodeposition, Proceedings of the International Conference on Concrete Repair, Rehabilitation and Retrofitting, Cape Town, (2008).

[17] British Standards Institution, Cement: Composition, Specifications and Conformity Criteria for Common Cements, London, (2000).

[18]British Standards Institution, Specification for Aggregates from Natural Sources for Concrete, London, (1992).

[19]British Standards Institution, Compressive Strength of Test Cubes, London, (2002).

[20]British Standards Institution, Testing Hardened Concrete, Depth of Penetration of Water under Pressure, London, (2000). 